\title{
The Quality of Grouper Cultivation Waters Around Bauxite Mining Site
}

\author{
Sayyidah Nur Habibah ${ }^{1}$, Khodijah $^{2}$, Endang Purnamasari
}

Integrated Natural Resources Management, Postgraduate Program, Andalas University, Padang, West Sumatra ${ }^{1}$, Master of Environmental Science, Raja Ali Haji Tanjungpinang Maritime University, Tanjungpinang ${ }^{2}$, Maritime Affairs and Fisheries Service of the Riau Islands Province ${ }^{3}$

*Correspondent Author: sayyidahabibah@gmail.com

\begin{abstract}
The purpose of this study was to determine the quality of the aquatic environment and the content of heavy metals, sediment, fish, and shellfish around the bauxite mining area. The main question is whether bauxite mining activities affect the quality of the surrounding waters. Further research needs to be carried out at the exact location during non-active mining activities as a comparison. Using the Atomic Absorption Spectroscopy (AAS) method, a field survey and heavy metal analysis are conducted. The results showed that the physicochemical properties of the water were categorized as polluted and unfit for fish farming. Five parameters, Cadmium (Cd), Timbal (Pb), Aluminum (Al), Nickel (Ni), and DO (dissolved oxygen), do not meet the quality standards of fish culture water and metal content in fish and shellfish bodies
\end{abstract}

Keywords: water quality, heavy metals, bauxite waste, grouper

\section{Introductions}

Development activities including mining, land clearing, and settlements must be responsible for ecosystem damage and environmental degradation. The consequences include the physical, chemical, and biological conditions of the soil and water will be wrong. Riau Islands Province has excellent potential for rock and metal mining materials, namely bauxite, tin, iron rock, granite, land sand, and sea sand. The geomorphology of Bintan Island and small islands in the Riau Islands, which are granite hills, make this area a source of bauxite. Bauxite is the raw material for aluminum. This mineral has been exploited since the Dutch colonial era*. Likewise, with Tanjungpinang City, the practice of mining bauxite has been going on since 2004, and in 2013 a temporary suspension was carried out, but illegal mining practices still exist today. Bauxite mining has affected the quality of the coastal waters of Tanjungpinang City. Especially in the seas of grouper cultivation on Los Island, Tanjungpinang City. The fishermen also report that ready harvesting fish died drastically.

Aquaculture is the cultivation and farming of aquatic organisms under controlled or semi-controlled conditions. In simple terms, aquaculture is agriculture: farmers cultivate water, not soil; depending on the species, the water can be fresh, brackish, or salty. In aquaculture, the primary forms of waste that are important in environmental management are suspended solids and dissolved nutrients [1]. The entry of pollutants into these waters will result in damage to various organs of the body; it is even possible to cause death and result in certain species that are susceptible to pollutants being lost/extinct so that the fish species found are reduced [2]. The entry of contaminants into the waters can affect the quality of the waters. If the material entering the water exceeds its assimilation capacity, the environmental carrying capacity will decrease. The Contaminants entering the waters will be scattered and undergo a deposition process, resulting in the spread of pollutants. The size of the range value of the measured parameters depends on the volume of diluent water, toxicity/intensity of pollutants, climate, depth, currents, topography, and geography, resulting in changes in physical, chemical, and biological properties, and the three will interact with each other. If one of the factors is disturbed or changed, it will impact the aquatic ecology [3].

Grouper is a seawater fish with substantial economic value and is the primary source of income for fishers [2] recently valued relatively high, especially for the consumption of large restaurants at home and abroad. The provision of seeds, so far, is still very dependent on the catch from nature. Not all coastal areas are suitable for grouper cultivation. Therefore the determination of the location must take into account several important factors, including a) being protected from big waves and storms, because fish are easily stressed and reduce their appetite when constantly hit by waves; b) being protected from the threat of pollution from industrial waste, agricultural waste and household waste; c) protected from ship traffic back and forth because apart from causing ripples, ship waste (diesel oil, etc.) will pollute the maintenance area. Water quality is one of the factors affecting the survival and growth of fish [4].

\footnotetext{
*Corresponding author: habibah@umrah.ac.id
} 
Considering that the waters around Los Senggarang Island are a source of livelihood for local fishers and a source of water supply for grouper aquaculture, it is necessary to consider maintaining the quality of the aquatic environment. To study the quality of the aquatic environment, the measurements were made on physical, chemical, and biological conditions.

The main findings of this study indicate that the pattern of bauxite mining activity has affected the decline in the quality of the surrounding aquatic environment. The release of tailings mud carried by rainwater into coastal waters, especially after heavy rains, causes changes in the quality of fish farming waters. There are differences in the level of pollution at the three observation stations. Stations I and II dominate the value of heavy metals, which can worsen the quality of the local water environment. The difference in each observation station has something to do with activities from the environment around Los Island, such as the mining industry. The environmental quality of the waters of Los Desa Senggarang Island in terms of the physicochemical properties of the water is in the medium category. Five parameters, Cadmium $(\mathrm{Cd})$, Timbal $(\mathrm{Pb})$, Aluminum (Al), Nickel $(\mathrm{Ni})$, and DO (dissolved oxygen), have not met the water quality standards for fish farming (Kep-51/MENKLH/2004). The content of heavy metals in the bodies of fish and shellfish has indicated that the distribution of heavy metals contaminates the aquatic organisms around the waters of the grouper cultivation location on Los Senggarang Island.

This study suggests periodic monitoring of the quality of the aquatic environment at fish farming locations, especially when mining activities stop. Bauxite miners should make efforts to repair the damage and pay attention to waste management by following the principles of sustainability.

\section{Literatur Review}

\subsection{Cultivation Business and Environmental Pollution}

Cultivation business is a business activity and technology to produce aquatic biota (fish in the broadest sense) in a controlled manner. The aquatic biota is produced to fulfill the food needs, improve the natural stocks, recreation, baitfish, ornamental fish, recycle organic materials, and industrial raw materials. The water quality is one of the factors affecting the survival and the growth of the fish [4], [2]. Growth is defined as a change in size. The variable that changes can be in the form of length or other physical dimensions, including volume, weight, and mass. It also could be either the whole body of the organism or various tissues of the organism. The change is also related to the content of protein, fat, or other chemical components of the body; the changes in the calorie content (energy) of the whole body are from its tissue components ([5], [6], [7]). Water pollution is an unwanted physical, chemical, and biological change in aquatic ecosystems that will cause harm to sources of life, living conditions, and industrial processes [8]. The Pollution of coastal waters has negative impacts and harmful effects on biota life, resources, marine ecosystems, and human health. It also affects the use-values of aquatic ecosystems, due to the disposal of materials or waste dumped into waters originating from human activities [9]. The sources of pollution in coastal and marine waters consists of seven classes, namely waste, industry, residential liquid waste (sewage), urban wastewater (urban stormwater), mining, shipping, agriculture, and aquaculture. In comparison, the primary pollutants contained in the waste disposal from the seven sources are sediment, nutrients, toxic metals, pesticides, exotic organisms, pathogenic organisms, garbage, and oxygen depleting substances (a substance that reduces dissolved oxygen in water) [10],[8]. Around the waters of Los Senggarang Island Island, there are many bauxite mining activities resulting in waste disposal into the seas. Types of industrial waste consists of five types, namely 1) dissolved organic materials, including toxic, biodegradable materials, 2) inorganic materials including nutrients, 3) insoluble organic materials, 4) insoluble inorganic materials, 5) radioactive materials.

\subsection{Heavy Metal Content in Water, Sediment and Biota}

Metal is a natural element obtained from the sea, erosion of mine rocks, volcanism, and so on [11], [12], [13]. Heavy metal is a term used generally for a group of heavy metals and metalloids whose densities are more significant than $5 \mathrm{~g} / \mathrm{cm}^{3}$ (Hutagalung et al., 1997). In water, heavy metals can be found in dissolved and insoluble forms. Dissolved heavy metals are metals that form complexes with organic and inorganic compounds, while undissolved heavy metals are colloidal particles and metal group compounds adsorbed on suspended particles [14]. The properties of heavy metals are unique; they cannot be destroyed naturally and tend to accumulate in the food chain through the biomagnification process. These heavy metal elements are usually closely related to pollution and toxicity problems [13]. The continuous disposal of industrial waste does not only pollute the aquatic environment but also causes the accumulation of heavy metals in sediments and aquatic biota, as shown in Fig.1.

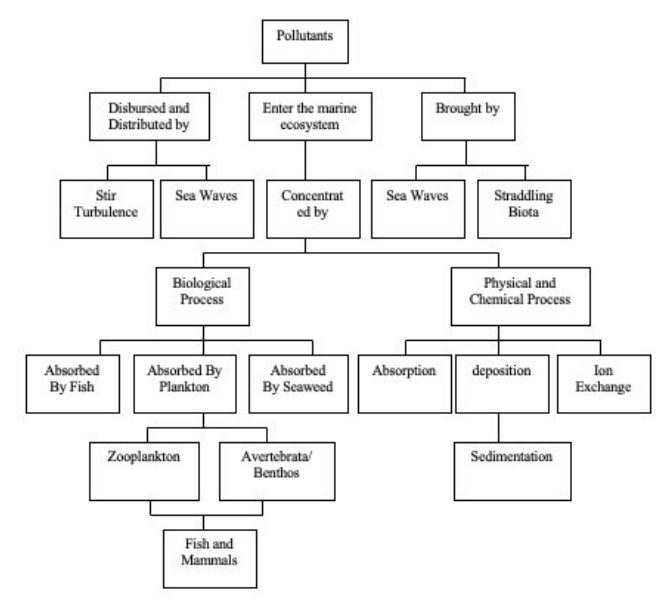


Fig. 1. Schematic of natural processes that occur when pollutants (heavy metals) enter the marine environment (EPA, 1973)

In the aquatic environment, three media can indicate heavy metal pollution; water, sediment, and living organisms. Cadmium $(\mathrm{Cd})$ is one of the heavy metals with extensive distribution in nature. In waters, $\mathrm{Cd}$ will precipitate because the sulfite compounds are difficult to dissolve. Cadmium metal or $\mathrm{Cd}$ will undergo a biotransformation and bioaccumulation process in living organisms (plants, animals, and humans). In addition, $\mathrm{Pb}$ is used as a fuel additive and lead pigment in paints which is the leading cause of increased levels of $\mathrm{Pb}$ in the environment [15]. Water is an essential element for the life of aquatic organisms. It is necessary to control multiple human activities that use the waters, either directly or indirectly. This is to maintain the quality of the waters that support the life of various organisms.

Table 1. Water quality standards for some heavy metals

\begin{tabular}{|l|c|c|c|}
\hline Logam & $\begin{array}{c}\text { Symb } \\
\text { ol }\end{array}$ & \multicolumn{3}{|c|}{ Standart } \\
\hline & & $\begin{array}{c}\text { Fishery } \\
(\mathrm{mg} /)^{1}\end{array}$ & $\begin{array}{l}\text { EPA } \\
(\mathrm{ppm})^{2}\end{array}$ \\
\hline Cadmi & & 0, & 0,0 \\
um & $\mathrm{Cd}$ & 0 & 043 \\
\hline & & 1 & 0,0 \\
Krom & $\mathrm{Cr}$ & 0 & 0,0 \\
& & 5 & 16 \\
\hline & & 0, & \\
Timbal & $\mathrm{Pb}$ & 0 & 0,0 \\
& & 1 & 65 \\
Seng & $\mathrm{Zn}$ & 0, & \\
\hline \multirow{2}{*}{ Mercur } & & 0 & 0,1 \\
$\mathrm{y}$ & $\mathrm{Hg}$ & 2 & 2 \\
\hline
\end{tabular}

Information :

1. PP No 82 of 2001

2. Environmental Protection Agency. 1973. Water Quality Criteria

Based on government regulations, the content of heavy metals that may enter marine waters has a limit. For more details, see Table 2.

Table 2. Seawater quality standard criteria for marine biota (MENKLH, 2004)

\begin{tabular}{lcc}
\hline Parameter & Unit & $\begin{array}{c}\text { Quality } \\
\text { standards }\end{array}$ \\
\hline Mercury & $\mathrm{mg} / 1$ & 0,01 \\
$(\mathrm{Hg})$ & $\mathrm{mg} / 1$ & 0,001 \\
Cadmium & $\mathrm{mg} / 1$ & 0,008 \\
$(\mathrm{Cd})$ & & \\
\hline
\end{tabular}

\section{Timbal}

$(\mathrm{Pb})$

Sediment is the place where plants and animals live at the bottom. Sediment consists of organic material derived from decaying animals or plants, then sinks to the bottom and mixes with mud and inorganic materials, which generally come from weathering rocks [16]. Heavy metals enter the body tissues of living things in several ways, namely: the respiratory tract, digestion, and penetration through the skin. In the animal body, the metal is absorbed by the blood, binds to blood proteins then distributes to all body tissues. The highest metal accumulation is usually in detoxification (liver) and excretion (kidney). The proliferation of heavy metals in the body of organisms depends on the concentration of heavy metals in the water/environment, temperature, state of the species, and physiological activities [17], [18].

\section{Material and Method}

\subsection{Material}

For water quality measurement, the materials and tools used are displayed in Table 3. There are two water quality parameters measured, namely physical and chemical parameters.

Table 3. The Method of Water Quality Measurement

\begin{tabular}{|c|l|l|l|}
\hline No & Parameter & \multicolumn{1}{|c|}{ Tools } & Description \\
\hline \multirow{4}{*}{1} & Physics & & \\
& Water & Thermometer & Insitu \\
& temperature & Gravimetric & Laboratory \\
& TSS & Turbidimeter & Laboratory \\
& Turbidity & refractometer & Insitu \\
& Salinity & & \\
\hline \multirow{6}{*}{2} & Chemical & & \\
& pH & pH meter & Insitu \\
& $\begin{array}{l}\text { Dissolved } \\
\text { Oxygen }\end{array}$ & DO meter & Insitu \\
& Setals (Cd, & & Laboratory \\
& Cu, Pb, Al, & & \\
& Ni, As) & & \\
\hline
\end{tabular}

\subsection{Method}

Sampling was held at three stations selected based on the types of activities in the vicinity that could cause pollution. At each station, three repetitions were done. The determination of the station is as follows:

The station I: East of Los Island Towards Sebauk The station II: Los Island Grouper Floating Cages The station III: West of Los Island Towards Tanjungpinang City

At each observation station, the water and sediment samples were taken to analyze the water quality parameters and heavy metal observations. Meanwhile, the marine biota samples in the form of grouper and shellfish were taken to the station II, used for rich metal analysis to see the content of heavy metals in the body of fish and shellfish. 
The method of taking and handling water samples and water quality methods refers to the APHA (1989). Heavy metal is analyzed using atomic absorption spectrophotometry (AAS), by using the principle-based Lambert-Beert law the amount of light absorbed is directly proportional to the content of the substance.

Measurement of Heavy Metal Content for Fish requires 5 grams of organs for AAS analysis. Then weighed, carried out dry ashing after removing of organic matter by dry ashing, the residue dissolved in dilute acid. The solution is dispersed in a flame in the AAS apparatus. So, The absorption/emission of the metal can be analyzed and measured at specific wavelengths. To get the actual concentration of heavy metals, use equation (1):

$$
\text { TotalK }=\frac{K A A S x V o l}{\text { DryWeight }}
$$

For the measurement of heavy metal content in water, use: 1) $500 \mathrm{ml}$ seawater sample filtered with 0.45 $\mathrm{m}$ filter paper, 2) $\mathrm{pH}$ sets in the range of 3.5-4 by adding concentrated HNO3, 3) Added $1 \mathrm{ml}$ concentrated HNO3 solution, 4) Added $5 \mathrm{ml}$ of acetate buffering mixture, 5) Added $5 \mathrm{ml}$ of ammonium pyrrolidine dithiocarbonate (APC), shaken for about 5 minutes, 6) Added $10 \mathrm{ml}$ of organic solvent methyl isobutyl ketone (MIBK), shaken for about 3 minutes and allow to cool to separate phases, 7) accommodated the water phase. This aqueous phase uses to prepare laboratory and standard blank solutions, 8) Added $10 \mathrm{ml}$ of double ion-free distilled water (DW, dd), and shaken for about 5 seconds, and let the two phases separate. Discard the aqueous phase, 9) Add $1 \mathrm{ml}$ of concentrated $\mathrm{HNO} 3$, and shake briefly. Leave for about 15 minutes, 10) Add $9 \mathrm{ml}$ of ion-free double distilled water and shake for about 2 minutes, let two phases separate, 11) The aqueous phase is collected and ready to be measured by AAS using an air-acetylene flame.

To measure the heavy metal content in the sediment; 1) put each sediment sample into a Teflon beaker evenly so that it undergoes a complete drying process, 2) the sediment sample is dried in an oven at $1050 \mathrm{C}$ for 24 hours, 3) the sediment sample is then dried and ground until smooth, 4) each sample of sediment; was weighed approximately 4 grams with a digital weighing device, 5) the sample of sediment was put into a closed Teflon beaker, 6) then $5 \mathrm{ml}$ of aqua regia solution was added and heated at $1300 \mathrm{C}, 7$ ) after all the sediment has dissolved, heating is continued until dried and then cooled to room temperature and transferred to a polyethylene centrifuge, 8) water is added to it until the volume reaches $30 \mathrm{ml}$ and allowed to settle, then collect the aqueous phase. Then it is ready to be measured by AAS using an air-acetylene flame.

The analysis and the data presentation are presented descriptively; secondary data (geographical and demographic conditions) and primary data (water quality parameters and heavy metals found in water, sediment, fish, and shellfish).

\subsection{Water Quality}

Sampling was carried on to three observation stations. Some water quality parameters are measured; dissolved Oxygen (DO), temperature, salinity, TSS, and $\mathrm{pH}$. Based on the analysis in the laboratory, the water quality is presented in Table 4.

Table 4. Water quality at each observation station

\begin{tabular}{|c|c|c|c|c|c|c|}
\hline \multirow{2}{*}{$\begin{array}{c}\text { Statio } \\
\mathbf{n}\end{array}$} & \multicolumn{6}{|c|}{ Water Quality Parameters } \\
\cline { 2 - 7 } & DO & Temp & Sal & TSS & pH & Turb \\
\hline I & 2,3 & 29,4 & 35 & 4,95 & 8,25 & 1,1 \\
\hline II & 3,1 & 28,9 & 35 & 14,2 & 8,05 & 3,2 \\
\hline III & 8,7 & 29,3 & 35 & 2,13 & 8,00 & 0,2 \\
\hline
\end{tabular}

The analysis of heavy metal content, namely $\mathrm{Cd}$, $\mathrm{Cu}, \mathrm{Pb}, \mathrm{Al}, \mathrm{Ni}, \mathrm{As}$ in water and sediment is displayed in table 9 below. The description of heavy metals in the water above indicates that the water are contaminated, although it has not shown a high level of pollution. Compared to the quality standard according to Kep51/MENKLH/2004, to conserve the marine biota and fish farming, there are five physicochemical parameters of water that do not meet the quality standards, namely Cadmium (Cd), Timbal (Pb), Aluminum (Al). ), Nickel (Ni), and DO (dissolved oxygen). Looking at the physicochemical parameters of the water mentioned above, the water quality in Los Island, Senggarang Village, is no longer suitable for fish cultivation. Heavy metals in water will be absorbed by aquatic biota either directly or through their food. These heavy metals are not immediately lethal but have bioaccumulation in the body of organisms; up to a certain amount can cause specific toxicity. Based on the level of toxicity, heavy metals range from high toxicity to low toxicity, respectively, $\mathrm{Hg}, \mathrm{Cd}, \mathrm{Cu}, \mathrm{Zn}, \mathrm{Ni}, \mathrm{Pb}, \mathrm{Cr}, \mathrm{Al}$, and $\mathrm{Cu}$. However, this sequence may change depending on the species and water conditions.

\subsection{Heavy Metal Content in Water, Sediment and Biota}

\subsubsection{Heavy Metals in Water and Sediment}

Based on the impact caused by pollution by heavy metals, especially in water bodies, it is necessary to have a concentration range or threshold value of metal concentrations recommended to enter and be in the aquatic environment. The heavy metals observed were cadmium $(\mathrm{Cd})$, Copper $(\mathrm{Cu})$, Timbal $(\mathrm{Pb})$, and other toxic metals such as Aluminum (Al), Nickel (Ni), Arsenic (As). The results of the analysis of heavy metal content in water are shown in Figure 2.

\section{Results}




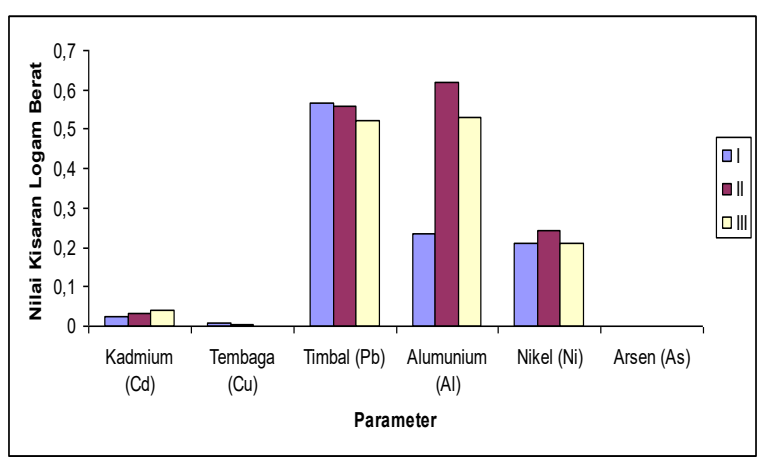

Fig. 2. Value range of heavy metal content in water per station

$\mathrm{Cu}$ content in water at each observation station ranged from 0.002 to $0.007 \mathrm{mg} / \mathrm{l}$. The value of $\mathrm{Cu}$ content for water is still below the quality standard (Kep-51/MENKLH/2004), which is $0.008 \mathrm{mg} / \mathrm{l}$, both for conservation or marine biota and fish cultivation. The $\mathrm{Pb}$ content in the water at each observation station ranged from 0.521 to $0.566 \mathrm{mg} / \mathrm{l}$. The lowest levels are at the station III, and the highest is at the station I. The results of the analysis of heavy metal content in the sediment are shown in Figure 3.

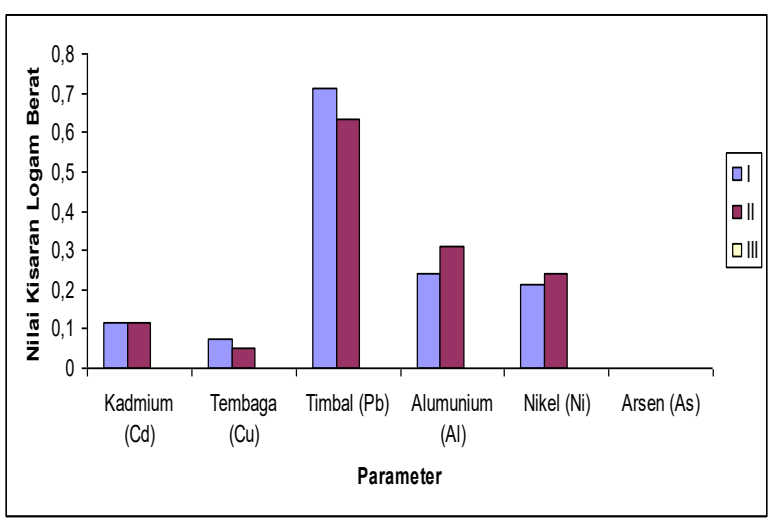

Fig. 3. The value of the range of heavy metal content in the sediment at each station

The $\mathrm{Cu}$ content in the sediment ranges from 0.053 to $0.076 \mathrm{mg} / \mathrm{l}$. The $\mathrm{Cu}$ content value for sediment is much higher than the quality standard (Kep51/MENKLH/2004). Moreover, it has exceeded the threshold for the station I and the station II. It is certain that gradually this area has begun to be polluted by $\mathrm{Cu}$ metal. The $\mathrm{Pb}$ content in the sediment ranged from 0.634 to $0.711 \mathrm{mg} / \mathrm{l}$. The lowest level was at station II, and the highest was at station I. From this value, it is known that the state of the content at each station had exceeded the permissible threshold for fish farming $(0.008 \mathrm{mg} / \mathrm{l})$.

Group of Experts on the Scientific Aspects of Marine Pollution (DESAMP), 1985, stated that $\mathrm{Pb}$ can interfere with the life of marine biota and can endanger human health. In general, the effect of $\mathrm{Pb}$ on marine biota depends on the form of the compound. The impact of inorganic $\mathrm{Pb}$ is generally only seen at concentrations of more than $100 \mathrm{~g} / \mathrm{l}$. The impact of $\mathrm{Pb}$ on other marine biota is to inhibit growth and reduce photosynthetic activities.
The content of Aluminum (Al) at each observation station (Figures 2 and 3), both in water and sediment, has exceeded the quality standard (Kep51/MENKLH/2004), which is $0.01 \mathrm{mg} / \mathrm{l}$, both for marine biota conservation and aquaculture fish. The highest distribution of aluminum content in water was at station II (0.621), followed by III (0.531), and the lowest was at station I (0.234). Meanwhile, the highest aluminum content in the sediment was at station II (0.312) and the lowest $(0.241)$ at the station I. The content of Nickel (Ni) in the water at each observation station is ranged from $0,211-0,241 \mathrm{mg} / \mathrm{l}$. While the content contained in the sediment ranges from $0,211-$ $0,241 \mathrm{mg} / \mathrm{l}$. The value of $\mathrm{Ni}$ content for water and sediment has exceeded the quality standard (Kep$51 / \mathrm{MENKLH} / 2004$ ), which is $0.05 \mathrm{mg} / \mathrm{l}$, both for conservation or marine biota and fish cultivation.

For Arsenic (As) content in water and sediment, each observation station did not indicate the presence of As pollutants in the waters. The description of heavy metals in the water above indicates that the water are contaminated, although it has not shown a high level of pollution. Compared to the quality standard according to Kep-51/MENKLH/2004, to conserve marine biota and fish farming, there are five physicochemical parameters of water that do not meet the quality standards, namely Cadmium (Cd), Timbal (Pb), Aluminum (Al). ), Nickel (Ni), and DO (dissolved oxygen). Looking at the physicochemical parameters of the water mentioned above, the water quality in Los Island, Senggarang Village, is no longer suitable for fish cultivation. Heavy metals in water will be absorbed by aquatic biota either directly or through their food. These heavy metals are not immediately lethal but have bioaccumulation in the body of organisms; up to a certain amount can cause specific toxicity. Based on the level of toxicity, heavy metals are ranged from high toxicity to low toxicity, respectively, $\mathrm{Hg}, \mathrm{Cd}, \mathrm{Cu}, \mathrm{Zn}, \mathrm{Ni}, \mathrm{Pb}, \mathrm{Cr}, \mathrm{Al}$, and $\mathrm{Cu}$. However, this sequence may change depending on the species and water conditions. 


\subsection{The content of heavy metals in the body of fish and shellfish}

The test fish studied were grouper and shellfish kept in aquaculture at station II. In monitoring the environmental pollution, water biota analysis is very critical than water quality analysis. The analysis of the heavy metals contents, namely $\mathrm{Cd}, \mathrm{Cu}, \mathrm{Pb}, \mathrm{Al}, \mathrm{Ni}$, $\mathrm{As}$ in the fish body, is displayed in Figure 4.

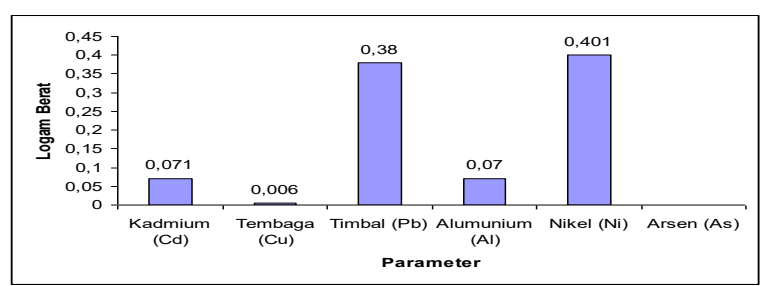

Fig. 4. The content of heavy metals in the body of fish

Based on Fig. 4 \& Fig. 5, it is known that the metal content in the fish and shellfish bodies indicates the heavy metals penetrate the aquatic organisms living in these waters.

Metals contaminated in fish bodies are cadmium $(\mathrm{Cd})$, copper $(\mathrm{Cu})$, Timbal $(\mathrm{Pb})$, Aluminum (Al), and Nickel (Ni) (Figure 9). Meanwhile, in shellfish, almost all heavy metals contaminated the shells, except for arsenic (Figure 4). That means that the metal content in both the fish and shellfish bodies has exceeded the threshold.

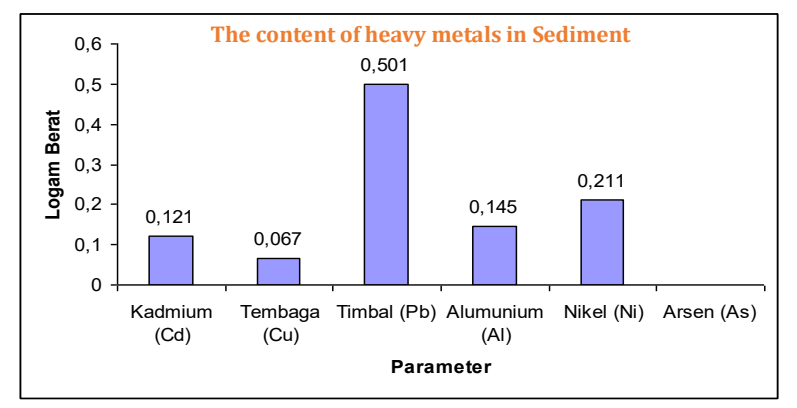

Fig. 5. Heavy metal content in shellfish

\section{Discussion}

Bauxite is one of the mining materials with excellent potential for the Riau Islands Province for the mining industry and increases local revenue. However, after running for a long time, the mining business (from 2004 until now) has not shown management with the principle of sustainability. Complaints from the community around the mining area, which experienced a decline in production and income from their business, indicate a negative impact from mining activities so far. This study shows results that prove there have been indications of water pollution in the environment around the mining site. Five parameters, Cadmium $(\mathrm{Cd})$, Timbal $(\mathrm{Pb})$, Aluminum (Al), Nickel (Ni), and DO (dissolved oxygen), have not met the water quality standards for fish farming (Kep-51/MENKLH/2004). The content of heavy metals in the bodies of fish and shellfish has indicated that the distribution of heavy metals contaminates the aquatic organisms around the waters of the grouper cultivation location on Los Senggarang Island.

This research took place at the location of fish farming waters around the bauxite mining site. Whereas, the previous study was conducted on coastal waters where there were no mining activities. The results showed that water pollution was caused by population density [19], pH, total ammonia, nitrate, and phosphate [2], [20]. The heavy metal content in the waters comes from the contribution of $\mathrm{Pb}$ from motor vehicle exhaust [21], and the content of cadmium in shrimp in ponds [22]. The decline in water quality also affects the diversity of other types of biota in the surrounding area. Further, the results found [23] that the seagrass dominance index in the waters of Los Island was categorized into a low group with a high species uniformity index. Declining water quality also disrupts shellfish-like organisms, such as bivalves [24].

Recommendations from this study need to conduct systematic research on the aquatic environment of fish farming and compare the quality of the waters when mining activities are active and when mining is not active. Therefore, it can be an essential input for policymakers in making plans for the management of cultivation areas and the management of bauxite mining waste by applying the principles of sustainability.

The limitation of this research is that it has not collected data when the bauxite mining activities are not actively operating. However, research on the quality of the waters around the mining site needs to be conducted periodically.

\section{Conclusion}

The study results concluded that there had been a decrease in water quality at the Los Tanjungpinang Island fish farming location due to bauxite mining.

The novelty of this research examines the impact of heavy metal content on the mortality of grouper cultured in floating cages; with the test materials on fish meat samples, shellfish, mangrove roots, and substrates on the bottom of the sea waters around the cultivation. The practice of these bauxite mining activities has not considered the principles of sustainability.

The environmental quality of the waters of Los Desa Senggarang Island in terms of the physical and chemical properties of the waters is in the medium category. Five parameters, Cadmium $(\mathrm{Cd})$, Lead $(\mathrm{Pb})$, Aluminum (Al), Nickel (Ni), and DO (dissolved oxygen), do not meet the water quality standards for fish farming (Kep-51/MENKLH/2004). The content of heavy metals in fish and shellfish bodies indicates that the distribution of these heavy metals has polluted aquatic organisms around the waters of grouper cultivation sites on Los Senggarang Island.

\section{Acknowledgment}

The researcher thanks those who facilitated the laboratories for examining the research samples; the 
Laboratory of the Faculty of Marine and Fishery Sciences UMRAH, the Aquaculture Environment Laboratory, Faculty of Fisheries, Bogor Agricultural University, and the NGO Fisherwomen Center, who have assisted in funding this research.

\section{References}

1. A. B. Dauda, A. Ajadi, A. S. Tola-Fabunmi, and A. O. Akinwole, Aquaculture and Fisheries 4, 81 (2019).

2. B. Hamuna, R. H. R. Tanjung, S. Suwito, H. K. Maury, and A. Alianto, Jurnal Ilmu Lingkungan 16, 35 (2018).

3. M. El-Dairi and R. J. House, 285 (2019).

4. S. \& Y. Panggabean, Jurnal Akuakultur Rawa Indonesia 4, 67 (2016).

5. H. Ali, E. Khan, and I. Ilahi, Journal of Chemistry 2019, (2019).

6. WWF Indonesia, WWF Indonesia edisi 2, 1 (2015).

7. S. Literate and J. I. Indonesia, 5, 274 (2020).

8. I. Bashir, F. A. Lone, R. A. Bhat, S. A. Mir, Z. A. Dar, and S. A. Dar, Bioremediation and Biotechnology: Sustainable Approaches to Pollution Degradation 1 (2020).

9. Hamzah, Thesis, IPB (2012).

10. N. Akhtar, M. I. Syakir Ishak, S. A. Bhawani, and K. Umar, Water 13, 2660 (2021).

11. A. Andayani, I. Koesharyani, U. Fayumi, R. Rasidi, and K. Sugama, Oseanologi Dan Limnologi Di Indonesia 5, 135 (2020).

12. A. Government, 1 (2016).

13. Andhani \& Husaini, Logam Berat Sekitar Manusia (2017).

14. E. Rochyatun, M. T. Kaisupy, and A. Rozak, MAKARA of Science Series 10, 35 (2010).

15. H. Darmawan, H. H. Darmawan, and A. A. Masduqi, Jurnal Teknik ITS 3, D16 (2014).

16. R. Commission, (2001).

17. I. Ismail, S. Soviana, and Y. Ridwan, Jurnal Riset Veteriner Indonesia 2, 41 (2018).

18. K. Haryono, Mulyono, Jurnal Ilmu Dan Teknologi Kelautan Tropis 9, 1 (2017).

19. A. D. Bank, ASIAN DEVELOPMENT BANK INDONESIA Country Water Assessment Indonesia Country Water Assessment (2016).

20. D. Azizah, Dinamika Maritim 6, 47 (2017).

21. Patang, Dampak Logam Berat Kadmium Dan Timbal Pada Perairan (2018).

22. G. Valentino, A. A. Damai, and H. Yulianto, EJurnal Rekayasa Dan Teknologi Budidaya Perairan 6, 705 (2018).

23. Syamsuar, (2015).

24. Zannah \& Susetya, Energies 6, 1 (2018). 